\title{
GOVERNO LULA E "REFORMA UNIVERSITÁRIA": PRESENÇA E CONTROLE DO CAPITAL NO ENSINO \\ SUPERIOR*
}

Lalo Watanabe Minto*

$\mathcal{E}$

m Os empresários e a educação superior, José Rodrigues analisa as propostas do empresariado brasileiro para a reforma da educação superior nas últimas duas décadas, dando enfoque às suas repercussōes sobre as atuais propostas de "reforma universitária" do governo Lula. ${ }^{1}$

Rodrigues explora os pontos de convergência e de divergência existentes entre as propostas das duas principais frações da classe burguesa interessadas na educação. Seu pressuposto é o de que os empresários industriais e os do ensino (a nova burguesia de serviços), representados pela Confederação Nacional da Indústria (CNI) e pelo Fórum Nacional da Livre-Iniciativa na Educação, respectivamente, têm como fim a transformação da educação em mercadoria. Destaca, contudo, que ambos guardam certas particularidades, constituindo o que o autor denominará a "dupla face" do processo de mercantilização da educação.

A educação-mercadoria é a forma de privatizar o "serviço" educação, alvo do empresariado do ensino, interessado na organização do setor como atividade comercial. Não interessa a esta nova burguesia de serviços a existência de qualquer mecanismo de controle estatal sobre o campo educacional. Suas propostas estariam, portanto, em total acordo

* Resenha do livro de José Rodrigues, Os empresários e a educação superior (Campinas: Autores Associados, 2007. 95p.).

** Doutorando da Faculdade de Educação da Universidade Estadual de Campinas (UnICAmP) e pesquisador do Instituto Brasileiro de Estudos Contemporâneos (IBEC/SP). E-mail: lalowm@yahoo.com.br 
com os pressupostos do neoliberalismo: desregulamentação estatal e livre-ação das "forças do mercado".

A mercadoria-educação é a forma de privatizar o "insumo" educação, alvo dos empresários industriais, interessados, sobretudo, nos ganhos de produtividade e na ampliação da mais-valia dos processos produtivos, por meio da "potencialização" gerada com a qualificação do trabalho (intuito da busca pela competitividade). Para esta fração da burguesia interessaria, em tese, a existência de controles estatais mínimos sobre a educação superior, em especial a pública, que lhe serviria como fornecedora cativa de força de trabalho qualificada.

Embora faça a distinção supramencionada, é importante ressaltar que o autor não trabalha numa perspectiva dual, mas sim dialética, que mostra a relação que ambas as formas da privatização mantêm com o processo de valorização do capital em geral. No caso do Brasil, sob a forma particular de subordinação aos ditames da economia internacional.

Como, então, o atual projeto de reforma universitária expressa o interesse geral do capital sobre a educação superior? As respostas de Rodrigues nos indicam que há pontos de convergência e divergência: ambas as frações burguesas convergem ao conceber a educação como fator decisivo para a inserção do Brasil na economia internacional, de modo competitivo, e a privatização como a melhor forma de produzila. E divergem quando o assunto é a regulação jurídico-estatal. A idéia de adequar a universidade pública à lógica da competitividade, defendida pelos industriais e pelo governo federal, incluiria, entre outras coisas, a sua expansão, o que vai de encontro aos interesses da burguesia educacional de serviços, que se diz defensora da livre-iniciativa privada na educação. É lícito lembrar que esta última é herdeira direta do próprio desmonte da rede pública de ensino, cujo contingenciamento histórico permitiu o seu crescimento. Contudo, a despeito das divergências que possam existir, o autor conclui que:

Há uma convergência geral entre os interesses dos empresários do ensino e dos empresários industriais, que confluem e se materializam, mesmo que de forma às vezes conflituosa, nas ações do Poder Executivo. Tal confluência alicerça-se no fato de que ambas as formas do capital (capital mercantil educacional e capital industrial) pretendem transformar a educação em mercadoria (mesmo que especial). Isto é, o capital busca, através da transformação da educação em mercadoria, a mediação para a 
manutenção do seu interesse mais geral - a valorização do valor através da exploração do trabalho vivo. (Rodrigues, 2007, p. 86)

O presente trabalho, portanto, nos apresenta uma ampla visão sobre o sentido histórico das reformas do ensino superior brasileiro nas últimas duas décadas. Nesse processo, destacam-se três grandes tendências:

1) De reorganização do modelo de financiamento público ao ensino superior: de um lado, exercendo controle sobre a rede pública, exigindo-lhe eficiência e eficácia empresariais (também entendida como autonomia), o que se traduz na restrição de direitos e "flexibilização" das relações trabalhistas, no contingenciamento de gastos, na precarização das condições de trabalho, na introdução de metas como a venda de serviços e patentes, aferidas por pretensas "avaliações" externas etc. De outro lado, nas diversas formas de transferir recursos públicos para o setor privado (isenções fiscais, financiamentos diretos, redução de encargos trabalhistas, compra de vagas etc.).

2) Da diferenciação das instituições e diversificação do modelo de ensino ("pluralidade"). Aqui o objetivo também é duplo: de um lado, atender às demandas do setor produtivo (integração universidade-empresa), adequando os conteúdos ensinados e as pesquisas realizadas nos chamados "centros de excelência"; de outro lado, atender à nova burguesia de serviços, que não deseja oferecer senão um ensino de baixo custo, despreocupado com a qualidade e livre de controles governamentais. Desta tendência resultam duas demandas essenciais e inadiáveis para os empresários em geral: quebrar o modelo de indissociabilidade entre ensino, pesquisa e extensão e estimular novas modalidades de formação e de pesquisa, como cursos de curta duração, ensino a distância, ensino tecnológico voltado às "profissōes emergentes", pesquisa "aplicada” etc. Trata-se, portanto, de promover uma dupla "flexibilização": das próprias instituiçóes e da relação entre elas.

3) Da adequação da gestão educacional às demandas por competitividade, permitindo a participação dos empresários na formulação de políticas, "flexibilizando" o trabalho docente e 
permitindo que os mesmos prestem serviços de ensino e pesquisa ao setor privado como estímulo ao empreendedorismo, desburocratização das contratações e licitações públicas, introdução de metas para a venda de serviços, enfim, implantação de uma "atitude empresarial” nas instituições públicas.

Vê-se, assim, que a velha dualidade da educação superior se intensifica nas atuais propostas da burguesia brasileira. Nota-se também que não se trata apenas da velha oposição ensino de qualidade para as elites econômicas e de má qualidade para as demais camadas da população. É mais do isso. O setor educacional se converte em espaço ampliado para a acumulação do capital. As duas formas da mercantilização expressam os modos pelos quais a mercadoria "se materializa no campo da formação humana", criando esta mercadoria especial, como a denomina José Rodrigues.

Sabemos, pois, que o controle do capital sobre a produção do conhecimento e da ciência produziu inúmeras atrocidades ao longo da história. O que dizer, então, dos riscos que se abrem quando a mediação exercida pelo capital sobre a produção do conhecimento e sobre a formação humana torna-se direta? A mercantilização da educação é caminho aberto para a barbárie como forma de (des)regulação social. Para lutar contra esta tendência é preciso, antes de tudo, compreender suas amplas dimensões e a profundidade com a qual já penetrou o campo da educação superior. Este pode ser um primeiro passo e é, a nosso ver, a grande contribuição do trabalho de Rodrigues.

\section{Nota}

1. A atual proposta de "reforma universitária" encontra-se em sua quarta versão, apresentada pelo Executivo como PL n. 7.200/2006, que tramita no Congresso Nacional apensado a dois projetos anteriores, o PL n. 4.212/04, que, por antiguidade, tornou-se o projeto principal, e o PL n. 4.221/04. 